\title{
The effect of educational videos "they are us" on stigmatizing people with mental disorders
}

\author{
Sifa Eka Wardani ${ }^{1}$, Suci Ratna Estria ${ }^{2}$ \\ 1,2 Medical Surgical of Nursing Department, Universitas Muhammadiyah Purwokerto, Indonesia
}

\begin{tabular}{|c|c|}
\hline ARTICLE INFO & \multirow{8}{*}{$\begin{array}{l}\text { ABSTRp stigma educational video "they are us" aims to eliminating the stigma in } \\
\text { fikes students and shifting the negative stigma be a positive stigma against } \\
\text { people with mental disorders. This study aims to determine the stop-stigma } \\
\text { educational video entitled "They Are Us" towards students of Health and } \\
\text { Science Faculty. This study used a quasi-experimental method with one-group } \\
\text { pre-test and post-test designs. The research sample was } 166 \text { respondents, using } \\
\text { cluster random sampling technique. The instrument used was a stigma } \\
\text { questionnaire sheet adapted from research conducted by Sasra (2018) in } \\
\text { Padang. The results of this study show the stigma of pre-test (39,40) and post- } \\
\text { test (62.28). The result of the Wilcoxon pre-test, post-test of stigma indicate } \\
\text { a significance level of } 0.000 \text { (P 0.05). In conclusion There is a significant } \\
\text { effect of giving the stop-stigma educational video entitled "They Are Us" } \\
\text { towards students of Health and Science Faculty. }\end{array}$} \\
\hline Article history: & \\
\hline Received: August 9, 2020 & \\
\hline Revised: August 20, 2020 & \\
\hline Accepted: August 30, 2020 & \\
\hline Keywords: & \\
\hline First keyword; Second keyword; & \\
\hline $\begin{array}{l}\text { Third keyword; Fourth } \\
\text { keyword; Fifth keyword }\end{array}$ & \\
\hline
\end{tabular}

This work is licensed under a Creative Commons Attribution 4.0 International License.

\section{Corresponding Author:}

Sifa Eka Wardani,

Medical Surgical of Nursing Department,

Universitas Muhammadiyah Purwokerto, Indonesia.

\section{INTRODUCTION}

Mental disorder is a syndrome or psychological pattern or behavior pattern that is clinically important, which occurs in individuals and the syndrome is associated with distress (for example, symptoms). pain, pain) or disability (inability to one part or several important functions) or accompanied by a significantly increased risk of dying, being sick, inability, or losing freedom [1]. Based on a preliminary survey conducted by researchers at the Faculty of Health Sciences, Muhammadiyah University of Purwokerto, the results of interviews conducted by researchers with 10 respondents, 9 people had a negative prejudice against people with mental disorders because they thought people with mental disorders should be isolated from the rest of society, they also think that mental illness is a burden on society, many of them do not want to live next to people who suffer from mental disorders because they think that people with mental disorders should be avoided and kept away because they often go berserk and disturb society and 1 respondent said that someone who shows signs of signs of mental disorders then immediately checked with the nearest health service, he also said that there is a need to provide much better tolerance, attitudes towards people with mental disorders in the community, and people with mental disorders must be given special attention befits any other human.

From the preliminary survey, students should have a positive stigma against people with mental disorders, because in practice students will act as reinforcers for people with mental disorders, as a relapse prevention, find treatment, help maintain adherence and rehabilitation of people with mental disorders. Students should also be able to think that people with mental disorders can be cured, people with mental disorders can take care of themselves, and people with mental disorders are not dangerous.

\section{RESEARCH METHOD}

This research is a quantitative study using amethod quasi experimental design with one group pre-test and post-test design. Location this research was conducted at the Faculty of Health Sciences, Muhammadiyah University of Purwokerto which was conducted in April-May 2020. Samples in this study calculated using the Slovin formula with the results of 166 people, then the technique sampling in this study using cluster sampling 
technique with results class $\mathrm{A}, \mathrm{B}, \mathrm{C}$ are 33 respondents, class D with 35 respondents and class $\mathrm{E}$ with 32 respondents.

\section{RESULTS AND DISCUSSIONS 3.1. Univariate analysis}

Table 1. Frequency distribution based on response $(n=166)$

\begin{tabular}{lcc}
\hline Characteristics & Frequency & Percentage \\
\hline Age & 37 & \\
19 years old & 106 & $22,3 \%$ \\
20 years old & 23 & $63,9 \%$ \\
21 years old & & $13,9 \%$ \\
Gender & 48 & \\
Male & 118 & $28,9 \%$ \\
Female & & $71,1 \%$ \\
Class & 33 & \\
Nursing A & 33 & $19,9 \%$ \\
Nursing B & 33 & $19,9 \%$ \\
Nursing C & 35 & $21,1 \%$ \\
Nursing D & 32 & $19,3 \%$ \\
Nursing E & &
\end{tabular}

From table 4.1 it is known that the characteristics of respondents based on age in the university's health science faculty Muhammadiyah Purwokerto with the age group of 19 years as much as $37(22.3 \%)$, the age group of 20 years as much as $106(63.9 \%)$, and the age group of 21 years as much as $23(13.9 \%)$. Based on data, the gender of the respondents were male as much as $48(28.9 \%)$, and female as much as $118(71.1 \%)$. Based on the level of education, that is, the respondent's college was $166(100.0 \%)$, and based on the semester, namely the 4th semester students were $166(100.0 \%)$.

The number of respondents in this study were 166 respondents using cluster sampling techniques that met the inclusion criteria. The results of the characteristics of the respondents obtained in this study were age, gender, level of education, semester, and class. Characteristics of respondents based on age indicate that most of the respondents are 19 years old, namely 37 respondents $(22.3 \%), 20$ years as many as 106 respondents $(63.9 \%)$, and 21 years as many as 23 respondents $(13.9 \%)$. in the faculty of health sciences, Muhammadiyah University of Purwokerto. This study previously conducted a data normality test using the KolmogorovSmirnov test because the sample was over 50 people with a $\mathrm{P}<0.005$, it was concluded that the data was not normally distributed. Then the researcher used the Wilcoxon test analysis, this test was carried out to analyze the results of the paired observations of the two data whether they were different or not. This test is used only for interval or ratio type data. However, the data does not follow the normal distribution [2].

The age distribution shows that most of the respondents are late adolescents who have had responsibilities towards family members or other people. A person's age is generally related to a person's level of knowledge. This is as stated by Notoatmodjo [3] who states that the factors that influence the level of knowledge, including age in the patient's family, affect the perceptive power and mindset of a person. As you get older your perception and mindset will also develop. The age of a person reflects maturity in making a decision, this shows that the older the person gets, the more his knowledge will be.

Nearly half of the respondents in this study were female with a total of $118(71.1 \%)$. This is supported by pila by research conducted on the effect of health education using video media on the stigma and public knowledge of people with mental disorders in the village of Central Sokaraja. Data obtained from most of the respondents were female, as many as $64(65.3 \%)$. Research conducted on differences in the effectiveness of face-to-face health education with social media on increasing family knowledge with schizophrenia, the results of the study showed that the majority of respondents were female, as many as 8 respondents $(80.0 \%)$ [4]. This is in line with research conducted by regarding the effect of psychoeducation on the level of knowledge about mental disorders stigma, the results of the study found that most of the respondents were female, as many as 86 respondents $(71.2 \%)$ and the rest were male- male as many as 14 respondents $(28.8 \%)$ [5]. This is also supported by research conducted regarding the level of knowledge, perceptions and attitudes of the community towards people with mental disorders (ODGJ) in Rowosari Village Semarang, it was found that most of the respondents were female, as many as 46 respondents (56.1) [6].

Sex differences do not directly affect a person's level of knowledge and stigma, but when given education, female respondents are more enthusiastic and their level of attention is very high. Attention is an awareness that accompanies an activity carried out and this is very important for one's interest in carrying out 
these activities. Attention is needed at the time of intervention so that the information provided through sociodrama education can be well received by respondents. All respondents in this study with the largest number of respondents were class D with 35 people $(21.1 \%)$. The level of education possessed by the respondent is sufficient to support the respondent in understanding the video information "they are us." [7] Stated that the level of education can increase knowledge about health. Education at the middle level in thinking and digesting a new experience to increase knowledge is more easily accepted.

\subsection{Bivariate analysis.}

Table 2. The mean value of stigma among PHC students before and after giving educational videos of the ODGJ stigma stop "they are us."

\begin{tabular}{lccccc}
\hline Variable & \multicolumn{2}{c}{ Before } & \multicolumn{2}{c}{ After } & $\Delta$ (difference before after) \\
\hline Stigma & Average & Min-Max & Average & Min-Max & \\
& 39,40 & $25-65$ & 62,28 & $40-85$ & 22,88 \\
\hline
\end{tabular}

Based on table 4.2 above, it is known that the mean stigma before being given an educational video The ODGJ stop stigma "they are us" is 39.40 with a standard deviation value of 9.659 while after being given the educational video the ODGJ stop stigma "they are us" the average is 62.28 with a standard deviation value of 8.835. Based on the results of the research, the value and average stigma of PHC students before being given the ODGJ stop stigma educational video "they are us" is 39.40 and after being given the ODGJ stop stigma educational video "they are us" increases to 62.28 thus it can be seen an increase in the average score of stigma among the students of physics. The results of research conducted by Pamungkas [8] regarding the stigma against People with Mental Disorders (ODGJ) in nursing students of Stikes Jenderal Achmad Yani Yogyakarta, the results showed that most of the students of the Nursing Study Program (PSIK) Stikes Jenderal Achmad Yani Yogyakarta has a stigma against patients with mental disorders in the moderate category of 78 people $(96.3 \%)$. This is in line with the research conducted by Shen, of medical education to eliminate stigma and discrimination associated with mental illness among future doctors, the effect of clerkship training on attitudes of Chinese students, After clerkship training, there is a significant increase [9]. In attitudes towards mental health as reflected in the total score on stigma $(103.4 \pm 8.6$ to $111.8 \pm 9.6$. The results of the study were strengthened by research conducted by Japar on the effect of counseling on schizophrenia on changes in knowledge and The stigma in students of SMK Karya Dharma class X found that the average stigma before counseling was 48.40 and after being given counseling the average stigma was 80.31 [10].

The results were in accordance with what said that the formation of stigma was influenced by many factors. one of which is the knowledge possessed by individuals Health education helps men Increase individual knowledge that will shift the existing stigma, so that people with mental disorders in the future are expected to be free from stigma and discrimination. In previous research conducted by Wahyu [11], it is said that the level of public knowledge is one of the supporting factors for stigma in society, stigma is all forms of physical and social attributes that reduce a person's social identity, disqualifying that person from complete social acceptance. As such, health education is considered an independent function of nursing practice and is the primary responsibility of the nursing profession.

States that the community's stigma against mental disorders can also be supported by the positive attitude of society and the government so that the stigma of society no longer prevents sufferers from carrying out activities, if the government and community leaders can give a positive response, the community will be influenced to give the same response [12]. It is hoped that the role of the government in tackling people with mental disorders can be done more in order to reduce the stigma of society, for example by frequently providing socialization and counseling about health, especially mental disorders. Many factors influence society's stigma against people with mental disorders. Health education which aims to increase knowledge about mental disorders has been shown in many studies to be one of the factors that most influence the occurrence of stigma. The difference in the change in the mean stigma of the PHC students before and after being given the ODGJ stop stigma educational video "they are us."

Table 3. The results of the mean stigma score of the PHC students before and after being given the ODGJ stop stigma educational video "they are us."

\begin{tabular}{|c|c|c|c|c|}
\hline \multirow[t]{2}{*}{ Variable } & \multicolumn{2}{|c|}{ Intervention } & \multirow[t]{2}{*}{$\mathbf{Z}$} & \multirow[t]{2}{*}{ p-value } \\
\hline & Before & After & & \\
\hline Stigma & 39.40 & 62,28 & $-11,033$ & 0,000 \\
\hline
\end{tabular}

Based on the results of thetest Wilcoxon on stigma in fikes students after giving the educational video stop stigma "they are us", it was found that the results were significant differences in the pre test and post test. 
seen from the significance obtained, which is equal to 0,000 or a significance value $<\alpha 0.05$, meaning that there is a difference in the stigma of the PHC students between before and after giving the educational video the ODGJ stigma stop "they are us."

The results of the analysis on the stigma variable showed a $\mathrm{p}$ value of 0,000 . The $p$ value was less than $\alpha 0.05$, which means that there was an effect of giving educational video ODGJ stop stigma "they are us" on the stigma of the fikes students. Giving educational videos to stop the stigma of ODGJ "they are us" helps increase individual knowledge and will shift the existing stigma, so that people with mental disorders in the future are expected to be free from stigma and discrimination. States that health education is synonymous with health education because both are oriented towards changing behavior, where counseling is an educational activity that aims to achieve changes in the behavior of individuals, families and communities in fostering and maintaining healthy behavior, as well as taking an active role in efforts to achieve a healthy health [13].

The results of a study conducted entitled the medical education do for eliminating stigma and discrimination associated with mental illness among future doctors? The effect of clerkship training on chinese student attitudes, it can be concluded that the results of data analysis using the Wilcoxon Signed Ranks test obtained a $p$-value of 0.001 . This is in line with the research conducted by Patten on the effectiveness of contactbased education for reducing mental illness related stigma in pharmacy students, with a p-value of 0.0001 [14]. This is also supported by research conducted by regarding the effect of counseling on schizophrenia on changes in knowledge and stigma in students of SMK Karya Dharma class X. The results showed the pre-post-test of knowledge and stigma showed a significance level of $0.0001(\mathrm{p} .<0.05)$ which means that there is an effect of counseling on schizophrenia on changes in knowledge and stigma in class X SMK Karya Dharma students.

These results indicate that the health education intervention carried out will have a positive impact in increasing one's knowledge [15]. The results of this study are also in line with theory which states that information obtained from both formal and non-formal education can have an effect so as to produce changes or increase in knowledge. Argues that knowledge or cognitive is the most important domain for the formation of one's actions. Behavior which is based on knowledge will be more lasting than behavior which is not based on knowledge. Knowledge is needed as a psychological boost in fostering daily stigma and behavior, so it can be said that knowledge is a stimulation to one's actions, especially the stigma that arises in society for people with mental disorders.

This result is in line with the research conducted which also concluded that health education can increase the knowledge of students of the Harapan Mekar Medan Education Foundation Junior High School. Video media relies on hearing and sight of the target, where the use of audiovisual involves all sensory organs, so the more sensory tools involved in receiving and processing information, the more likely the content of the information can be understood and retained in memory, and with the effects of moving images and images. Sound effects can make it easier for the audience to understand the content of the news so that they can increase knowledge.

Explains that in the health education process, apart from being influenced by teaching materials and learning facilities, the use of health education methods and aids will affect the desired outcomes of teachers. The implementation of health education with a more effective video playback method is due to the fact that the video method has the advantage of being able to display an object or event as the actual situation. Video increases memory retention because it is more interesting and easier to remember. States in his research that providing health education with videos can improve respondents' understanding. In line with research, using video media found an increase in knowledge after health education was carried out. Both of these studies explain that health education using the video method will increase caregiver knowledge. The video playback method can form the knowledge, attitudes and behavior of students from the results of capturing the five senses by students.

States in his research that providing health education with videos can improve respondents' understanding. In research using video media found an increase in knowledge after health education was carried out. Both of these studies explain that health education using the video method will increase knowledge caregiver. The video playback method can form the knowledge, attitudes and behavior of students from the results of capturing the five senses by students. The results of this study are in line with Purnama's research which states that video media is effective in increasing students' knowledge of the dangers of drugs at SMP Negeri 3 Mojosongo Boyolali [16]. Conducted a meta-analysis of 18 studies to test the effectiveness of audiovisual interventions in reducing preoperative anxiety in children. The results showed that audiovisual intervention was effective in reducing preoperative anxiety in children. Videos, multi-faceted programs, and interactive games are the most effective methods. Research concluded that there was an increase in parental knowledge after being given a presentation using powerpoints and videos for 30 minutes related to the oral health of babies. 


\section{CONCLUSION}

The results of the average stigma score of the PHC students before giving the ODGJ stop stigma educational video "they are us" is 39.40 and after giving the ODGJ stop stigma educational video "they are us "which is 62.28. This means that there is an effect of giving educational videos to stop the stigma of ODGJ "they are us" on the stigma of fikes students ( $p$ value 0,000$)$.

\section{Acknowledgements}

Thank you to the Kejobong Community Health Center for giving permission to researchers so that they can make educational videos of the stop stigma "they are us." Thank you to the Faculty of Health Sciences, Muhammadiyah University of Purwokerto who has given iji to researchers so that they can conduct research at the Faculty of Health Sciences, Muhammadiyah University of Purwokerto and have helped in the data collection process in this research.

\section{REFERENCES}

[1] E. Prabowo, Concept and Application of Mental Nursing Care, Jakarta: Nuha Medika, 2014.

[2] Sugiyono, Quantitative, qualitative, and R\&D research methodologies, Bandung: Alfabeta, 2009.

[3] Notoatmodjo, Health Behavior and Education, Jakarta: Rineka Cipta, 2010.

[4] Hayat, "Differences in the Effectiveness of Face-to-Face Health Education with Social Media on Increasing Knowledge of Families with Schizophrenia," Alauddin State Islamic University Makassar, Makassar, 2017.

[5] Alfianto, "The Effect of Psychoeducation on the Level of Knowledge about the Stigma of Mental Disorders," Journal of Health Sciences, vol. 2, no. 2, 2017.

[6] P. Sari, "Knowledge Levels, Perceptions and Attitudes of Society Towards People With Mental Disorders (ODGJ) in Rowosari Village, Semarang City," Muhammadiyah University Semarang, Semarang, 2018.

[7] Perry and Potter, Nursing Fundamentals Textbook, Jakarta: EGC, 2013

[8] Pamungkas, "Stigma Against People with Mental Disorders (ODGJ) in Nursing Study Program Students Stikes Jenderal Achmad Yani Yogyakarta," Media Health Sciences, vol. 5, no. 2, 2016.

[9] Shen, The Medical Education Do For Eliminating Stigma And Discrimination Associated With Mental Illness Among Future Doctors? Effect Of Clerkship Training On Chinese Students' Attitudes, US: National Library of Medicine, 2014.

[10] A. Japar, "The Influence of Counseling About Schizophrenia on Changes in Knowledge and Stigma in Class X SMK Karya Dharma Students Medical Education," Medical School Bandung Islamic University, Bandung, 2017.

[11] Wahyu, Mental nursing pocket book, Yogyakarta: Nuha Medika, 2012.

[12] Widjanarko, Society's Stigma against Mental Disorders, Jakarta: Gramedia Pustaka Utama., 2008.

[13] E. Sofian, Survey Research Methods, Jakarta: LP3ES, 2012.

[14] Patten, "Effectiveness of contact-based education for reducing mental illness-related stigma in pharmacy students: US National Library of Medicine," National Institutes of Health , US, 2012.

[15] Fauziah, "The Influence of Health Education on Preconceptual Nutrition on the Level of Knowledge, Attitudes, and Practices of Healthy Food Consumption of Premarital Women.," University of Indonesia, Indonesia, 2012.

[16] G. Purnama, "Description of Community Stigma Against Clients with Mental Disorders," Journal of Nursing Education, vol. 2, no. 1, 2013. 